\title{
Development Indicators and Soybean Production in Brazil
}

\author{
Marley Nunes Vituri Toloi ${ }^{1,2, *}$ (), Silvia Helena Bonilla ${ }^{1}\left(0\right.$, , Rodrigo Carlo Toloi ${ }^{2}$, \\ Helton Raimundo Oliveira Silva ${ }^{1}$ and Irenilza de Alencar Nääs ${ }^{1}$ (D) \\ 1 Postgraduate Program in Production Engineering, Paulista University-UNIP, Dr. Bacelar Street 1212, \\ São Paulo 04026-002, Brazil; shbonilla63@gmail.com (S.H.B.); kaa_ell@hotmail.com (H.R.O.S.); \\ irenilza.naas@docente.unip.br (I.d.A.N.) \\ 2 Federal Institute of the Mato Grosso, Rondonópolis 78721-520, Brazil; rodrigo.toloi@ifmt.edu.br \\ * Correspondence: marley.toloi@roo.ifmt.edu.br
}

check for updates

Citation: Toloi, M.N.V.; Bonilla, S.H.; Toloi, R.C.; Silva, H.R.O.; Nääs, I.d.A. Development Indicators and Soybean Production in Brazil. Agriculture 2021, 11, 1164. https://doi.org/10.3390/ agriculture11111164

Received: 26 September 2021 Accepted: 13 November 2021 Published: 18 November 2021

Publisher's Note: MDPI stays neutral with regard to jurisdictional claims in published maps and institutional affiliations.

Copyright: (c) 2020 by the authors. Licensee MDPI, Basel, Switzerland. This article is an open access article distributed under the terms and conditions of the Creative Commons Attribution (CC BY) license (https:// creativecommons.org/licenses/by/ $4.0 /)$.

\begin{abstract}
Due to its agricultural potential, land extensions, and favorable climate, Brazil is one of the largest producers and exporters of various agricultural products. A significant part of this production is placed in Mato Grosso, the primary national producer of several agricultural commodities. The soybean complex alone produced more than 33 million tons of soybean for the 2019/2020 harvest, representing $27 \%$ of national production. The economic potential that the soybean commodity represents is linked to the increase in demand for inputs, planted area, production, and productivity. Given these factors, the present study aims to analyze how the largest municipalities of soybean production behave, and the degree of interaction and positive associations between the economic potential promoted by soybean production and the economic/social development and environmental impacts in the Mato Grosso State, Brazil. The methodology was to categorize the thirty largest soybean producing municipalities, using the factor analysis method for selected indicators. The interpretation is made through the adoption of the Driver-Pressure-State-Impact-Response (DPSIR) framework. The results indicated that the groups formed are not homogeneous in terms of socioeconomic and environmental development. The three factors that formed, were interpreted using the DPSIR are characterized by the significant influence of the population, reflect on its development, how economic activities are other and not just agriculture. The second also belongs to the driver in the DPSRI framework group. It is associated with the soybean production indicator, implying larger planting areas, generating jobs focused on agricultural activities. The interpretation is made through the adoption of the Driver-Pressure-State-Impact-Response (DPSIR) framework. The results indicated that the groups formed are not homogeneous in terms of socio-economic and environmental development. The significant influence of the population characterizes the three found factors. The first reflects on the region's development and how other economic activities (not just agriculture) are carried on. The second also belongs to the driver in the DPSRI framework group, and it is associated with the soybean production indicator, generating jobs focused on agricultural activities. The third group, formed by municipalities in the Amazon region, with environmental factors associated with large geographical areas, extensive native forests, and more significant carbon sequestration, considers the DPSRI framework's impacts. Showing that there are behavior patterns and taking this into account is the optimal way to use the predictors appropriately. Municipalities are expected to be more reactive to some changes than to others to achieve a good level of development.
\end{abstract}

Keywords: soybean; factor analysis method; behavior; framework DPSRI

\section{Introduction}

The coalescence among chains and the farmers' skills makes Brazil a significant player in producing and exporting agricultural products through its great agricultural potential, large tracts of land, and favorable climate. Brazilian agribusiness grows quickly due to several factors and impacts the gross domestic product (GDP). This achievement was due 
to increased agricultural productivity, advanced technologies in irrigation and machinery, and monitoring systems and investments in research [1-3].

The world population growth, especially in developing countries driven by longevity, purchasing power, and change in eating habits, causes a growing global demand for water, food, and fiber, causing pressure on agriculture and demanding a development with more controlled use of natural resources [4]. According to the Ministry of Agriculture data, the gross value of agricultural production in 2019 reached more than BRL 600 billion [5]. The main exported products are sugar, coffee, corn, orange juice, cotton, and soy. Moreover, soy is currently considered the primary world source of vegetal protein [6], representing more than $32 \%$ of agricultural revenues [5]. The soybean production increase in Brazil has always been associated with scientific advances and technologies in the agricultural sector. Its technological advances in recent decades make evident significant changes in crop exploration, enabling its commercial cultivation [7]. This growth is stimulated by the demand for soybean to feed several meat chains and the production of biodiesel, food products, among others [8-11].

The soybean supply chain has been of great importance for generating foreign exchange for the country for increasing Brazilian international commercial trade. In half a century of cultivation, the area of soybean planted exceeded 36 million hectares and its production for the 2020 harvest was over 122 million tons ha, and the 2020 harvest was over 122 million tons [12,13]. Mato Grosso is responsible for a significant part of Brazilian production, being the main national producer of soybean and corn crops, generating foreign exchange, moving different segments of the economy [14]. Located in the central-west region of the country, the state has three different biomes: Amazon, Cerrado, and Pantanal, and is the state accounts for a significant part of Brazilian production, being the primary national soybean and corn production, generating trade, and moving different economy segments [14]. Mato Grosso state is located in the central-west region of the country. It has three different biomes Amazon, Cerrado, and Pantanal, and is the third-largest state in the country, behind only Amazonas and Pará. The region has 90 million ha in which 21\% are planted pastures. Over $10 \%$, corresponding to 9.3 million ha, are related to agriculture and forests, making the state a great national agricultural power and forests, making the state a great national agricultural power [15]. Within several supply chains related to the agricultural sector of Mato Grosso, the soybean complex produced more than 33 million tons of soybean in grain for the 2019-2020 harvest, and it represents an increase of almost $80 \%$ compared to the last ten years of cultivation. It is $27 \%$ of all national production, exported almost USD 9 billion, equivalent to 25 million tons of soybean [12,16,17]. The economic potential that the soybean commodity represents is linked to increased demand for inputs, increased planted area, increased production, and productivity. In this way, soybean production influences every individual who is directly and indirectly linked to it. The market income generated from soybean crops occurs before, during, and after its production. Therefore, soybean influences the inhabitants' income and, consequently, the quality of life and well-being of the people around it; The market income generated from soybean crops occurs before, during, and after its production. Therefore, soybean influences the inhabitants' income and, consequently, the quality of life and well-being of the people around it [18].

This study aims to analyze how the largest soybean producing municipalities interact with the economic potential promoted by soybean production and economic, social, and environmental development within the Driver-Pressure-State-Impact-Response (DPSRI) framework. The article is divided into five sections. In addition to the introduction, a literature review was completed related to this research theme. The following section is the used methodology, and next, the results are presented and discussed. Finally, the conclusions are shown driven by the objective of the research. 


\section{Theoretical Background}

Some studies in Brazilian literature have evaluated the influence of soybean production, approaching the relationship between the variables of soybean production in 150 producing cities compared with the variables of development and well-being of the population. It was evident that there is a significant relationship between soybean production and quality of life There is a significant relationship between soybean production and the quality of citizen's life. However, there were also places where the level of well-being of the population was not related to soybean production [18].

Another study analyzed the effects of soybean production in the cerrado of MATOPIBA (the group formed by the States of Maranhão, Tocantins, Piauí, and Bahia). In that previous study, the authors pointed out a concept of poor development: an uneven process of change that worsens the local population's material and social capacities. It is necessary to include all those involved, promoting the fair distribution of benefits and burdens between different social groups to develop appropriately [19]. On the other hand, the absence of inclusion leads to the systematic expropriation of resources and the destitution of local actors. This comes from dominant crop monocultures that lead to sustainability issues since soybean's expansion in MATOPIBA. This scenario reveals how it fails concerning development in general, as few people benefit. Most local rural residents, deprived of access to vital resources, such as water and food, are excluded from decision-making bodies, which lead to the concentration of income, land, and other natural resources in the hands of a few [19].

\subsection{Soybean Production and Its Impacts on Socio-Economic and Environmental Aspects}

The economic importance of soybean production is not restricted to producers, showing different destinations and purposes such as export in grain, bran, oil, and a source of protein for various meat chains around the world. As a result, numerous business and job opportunities related to industry, distribution, and the input market in these cities are created [18]. Some similar studies researched with soybean producers demonstrated a positive result regarding soybean production in terms of income and employment. However, although it does not employ many direct workers per ha, it indirectly provides other jobs in its supply chain $[10,20]$. This is reflected in the generation of income and the people's quality of life and well-being [18].

The Brazilian government has carried out actions to improve the social inclusion of small farmers, mainly for family farming, including soybean production for supply and production of biodiesel with the Social Fuel Seal. This program aims to help thousands of families across the country to cultivate and market oilseed crops such as soybeans. In Mato Grosso, several agrarian reform settlements were involved in this program. However, many of these small farmers are not the original occupants of the lands donated by the government. With the technical support of the large soybean farmers, small farmers manage to profit from soybean production on a small scale [10]. In 2017, 18.2 million people worked in the country's agribusiness sector, representing $20.1 \%$ of the workforce. These people are usually unqualified with little formal education. In addition, they are used to working informally with incomes lower than workers in other economic sectors [1].

Rural employment significantly contributed to the country's economic, social, and environmental development [4]. Employment opportunities outside the agricultural sector, through their sectoral linkages, lead to the development of upstream and downstream service sectors, such as agrochemical consulting companies, the downstream processing, emerging soybean crushing facilities, biodiesel and ethanol plants, and increased meat production, which are dependent on locally produced grains [20].

Regarding environmental aspects, agribusiness, as one of the main economic activities in Brazil, is a sector with significant representation in greenhouse gas (GHG) emissions [14]. Environmental degradation is directly linked to economic activities practised on the planet. Many analysts indicate the need to change the current economic development model [21]. Given these concerns, consumers worldwide have asked for more information about the 
origin, quality, and way the food they consume is produced and the impacts it can cause on the environment [22]. Brazil has several initiatives related to more sustainable production, such as increased productivity, use of degraded areas by extensive cattle raising, adoption of economically and environmentally sustainable practices, such as the integration of livestock farming (ILF), and, finally, the integration of crop-livestock forestry (ICLF) [23]. Actions such as these result in a reduction in chemical inputs and $\mathrm{CO}_{2}$ emissions through the reduced use of fuel and agricultural labor, enhancing the mitigation of greenhouse gases and carbon sequestration [24].

Regarding the soybean chain, the productive sector, soybean value chain, large soybean producing companies seeking to reduce environmental impacts, have been promoting several efforts in recent years, such as reducing deforestation, using the no-tillage system, and creating the soybean moratorium [25]. These listed actions are still not enough, as soybean production depends on inputs such as fertilizers, fuels, machinery, and pesticides, which help increase GHG emissions into the atmosphere and the product's carbon footprint [22]. Even in the face of several actions, there are concerns in Brazilian and worldwide about deforestation, deterioration of ecosystem services, loss of biodiversity, and the increase in carbon emissions. Deforestation in both biomes Amazon and Cerrado might damage regions' biodiversity [10].

According to some researchers, to achieve a sustainable agricultural system in Brazil, combining modern agriculture with high diversity and functional ecosystems and improving socio-economic conditions is necessary to reduce distribution inequalities [26]. Another worrying factor is social sustainability, widely criticized, as thinkers argue that economic growth bears fruit. Nevertheless, these are unevenly distributed, and the mechanism that produced the growth was mainly "throughput growth" ("extracts/produces/discards"), stimulated by consumption [27].

\subsection{The DPSIR Conceptual Framework}

The DPSIR conceptual framework was developed by the European Environmental Agency (EEA) [28] and has been widely used to model environmental problems. As stated by [29], its application outside the environmental arena is limited. The approach consists of identifying the linkages between "drivers- $\mathrm{D}$ " through "pressures-P" on different "states-S," as well as their consequential "impacts-I" on the system, leading eventually to "responses-R" from the society.

Drivers: Factors that cause changes in the system of interest. These forces can be social/demographic, economic/technological, or ecological and comprise positive and negative influences.

Pressure: Means through which drivers are expressed; all the activities and natural processes result from the driving forces.

State: Situation of the system of interest under current environmental and socioeconomic conditions.

Impacts: Modifications, caused directly or indirectly, in the state of the system of interest, which influences human well-being.

Response: Efforts to reduce the pressures, address the changes in "state," or prevent, repair, or adapt to the impacts. The actions can be voluntary, legally mandated, or incentive-driven.

The DPSIR framework was selected to structure the analysis and close the indicators within a logic framework. This framework allows identifying the drivers that promote changes at some levels, from land use to society, and to support the empirical analysis of agri-social-environmental linkages. Although cause-effect relationships are challenging to establish, models that show at least plausible relationships among variables generally have the most meaning for environmental decision-makers.

The inclusion on the same basis of these different aspects towards a more sustainable development motivated studies that applied the driving force-pressure-state-impactresponse (DPSIR) tool. It is possible to identify and describe processes and interactions 
in human-environmental systems using this analysis tool. In the case study carried out in Jiangsu Province in China (China), the concept and indicators of ecological integrity are used to assess indicators in the dimensions of the DPSIR between 2003 and 2006. In this case, productive/economic factors of agricultural development have become more efficient and brought benefits to society. However, there has been an increase in pressure on natural resources in general [30]. In the city of Ardabil in Iran, an assessment of the carrying capacity of four central districts showed that two of the four regions studied use the maximum capacity of the area according to the components used in the DPSIR. The DPSIR allows visualizing the 'status' or picture of human interactions/activities with ecosystems [31] simplistically. The challenge of converting more technical and scientific information into public policy can be reduced using the DPSIR.

In Brazil, studies aimed at public policies included the DPSIR in the field of water resources. In the search for better water demand management strategies in the Apodi-Mossoró river basin (RN-Brazil), the DPSIR identified flaws in the demand service system by analyzing four allocation strategies and variations in the conditions required reservoirs [32]. The mapping and diagnosis with the DPSIR method of sub-basins, such as the Mampituba River in southern Brazil, showed the primary pressure generating activities. These activities include agricultural, industrial, and urban, but the anthropic pressure is generally low [33]. Sensitive/negative and positive/benefit points revealed by the DPSIR analysis act as checks and balances that decision-makers can consider when designing and applying public policies.

\section{Methodology}

\subsection{Factor Analysis FA}

Factor analysis (FA) is a multivariate statistical method that analyzes several variables to reduce a large data dimension to a relatively smaller number of dimensions, components, or latent factors [34]. Factor analysis provides a way of reducing the dimensionality of the data. It enables the graphic representation of intersample and intervariable relationships offering latent variables to improve understanding and advance development trends. This technique has three main uses: understanding the structure of a set of variables, constructing a questionnaire to measure an underlying variable, and reducing a dataset to a more manageable size while retaining as much original information as possible [35]. The software used to process the data was the Minitab ${ }^{\circledR}$ with Quartimax as the rotation factor method. The number of factors was determined by the criterion of eigenvalues higher than one.

Indicators must be sensitive to the more relevant events, and they also have to be acquired with a determined and known frequency and offer credibility. In this way, data from recognized public and international sources were prioritized/; moreover, they must be available for municipalities [36] (Table 1).

GHG emissions calculations considered the inputs in manufacturing and their use at the farm (agricultural phase), as shown in Equation (1)

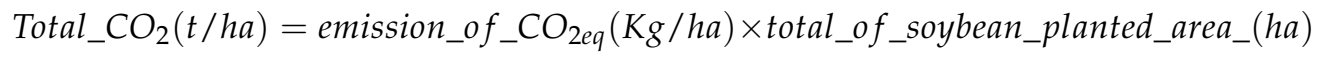

where Total $\mathrm{CO}_{2}$ is the total emission from the soybean crop area in each Biome. 
Table 1. Selected indicators to carry out the evaluation.

\begin{tabular}{|c|c|}
\hline Indicators & Source \\
\hline $\begin{array}{l}\text { Area of the municipality (ha) }{ }^{*} \\
\text { Soybean area (ha) } \\
\text { Soybean production (ton) }{ }^{* * *}\end{array}$ & [37] \\
\hline $\begin{array}{l}\text { Deforestation until } 2019 \text { (ha) })^{* * * *} \\
\text { Remanent biomes until } 2019 \text { (ha) } * * * * *\end{array}$ & [38] \\
\hline $\begin{array}{l}\mathrm{CO}_{2} \text { emission per soybean plantation (ton/ha) } \\
\text { (Equation (1)) }\end{array}$ & {$[36,39]$} \\
\hline
\end{tabular}

$\mathrm{CO}_{2}$ sequestration due to remanent biomes

Calculations based on remaining forests areas and according to their biome, made by the authors.

Global IFDM (Firjam index of municipal development, includes health, education, job [40] and income)

Jobs in other activities (except agriculture) Jobs in agriculture

Population

Formal jobs

Agriculture GDP

Other activities GDP

* Total area of municipality (ha); ${ }^{* *}$ Total area of soybean planted (ha); ${ }^{* * *}$ Total: soybean produced throughout the planted area $(\mathrm{t}){ }^{* * * *}$ Total deforestation of biomes by 2019 (ha); ${ }^{* * * * *}$ Total existing forests by biome until 2019 (ha) Total existing forests by biome until 2019 (ha); IFDM

Table 2 shows the description used on describes the calculations based on remaining forests according to their biome.

Table 2. Calculations based on remaining forests according to the biome.

\begin{tabular}{lll}
\hline Biome Soybean Crop Area (ha) & $\begin{array}{l}\text { Carbon Sequestration Potential Index } \\
\text { by Biome/ha TC/ha/year }\end{array}$ & $\begin{array}{l}\text { Carbon Sequestration Potential (t)/the } \\
\text { Total Remaining Forest (ha) }\end{array}$ \\
\hline Amazon & 12.5 & TCFA \\
Cerrado & 5.4 & TCFC \\
Pantanal & 5.4 & TCFP \\
\hline
\end{tabular}

* Source: [43]; TC = carbon metric ton continuous flow; TCFA = total carbon sequestration potential $(\mathrm{t}) /$ the total remaining forest (ha) in the Amazon biome; TCFC $=$ total carbon sequestration potential $(\mathrm{t}) /$ the total remaining forest (ha) in the Cerrado biome; TCFP $=$ total carbon sequestration potential $(\mathrm{t}) /$ the total remaining forest (ha) in the Pantanal biome.

The indicators of deforestation areas refer to areas deforested in 2019, according to data from the National Institute for Space Research (INPE). These areas were not necessarily deforested for soybean production, but in principle for logging, followed by livestock raising, and then into agricultural areas $[38,44,45]$. The remaining areas are the existing forests of each biome until the year 2019 [38].

As for the choice of social development indicator, we opted for the FIRJAN Municipal Development Index (IFMD) used by the Federation of Industries of the State of Rio de Janeiro. It is a human development indicator that annually monitors all Brazilian municipalities' social and economic development in three areas of activity employment and income, education, and health. The index varies between ( 0 and 1$)$. The closer to 1 , the greater the level of development of the location [40].

The choice of formal jobs indicates the development of each municipality in the generation of formal jobs. As for the employment indicator in other sectors, all formal jobs (mineral extraction, transformation industry, public utility industrial services, civil construction, commerce, public administration services) are included to distinguish between non-agricultural and agricultural jobs for each municipality [41]. Such an approach was 
made for the agricultural GDP and the other non-agricultural sectors considered (industry, services, administration, defense, education, and public health and social security) [42].

The selected indicators (Table 1) were organized and presented according to the DPSIR framework (Figure 1). The expansion and intensification of soybean are considered as a driver, as well as the population size. Population size influences the demand for land and resources to sustain the needs. These drivers are represented by soybean production and population. These two drivers combined are expressed through human activities and natural processes involved in supporting those. Area related to soybean production is included in this category, and jobs need to meet demands. The more visible effects at society/economic and environmental domains are GDP, remanent area, and $\mathrm{CO}_{2} \mathrm{emitted} /$ area. The total area is also included in this category since it represents the exert pressure on the environment. The associated environmental impacts are deforestation and the capacity of $\mathrm{CO}_{2}$ fixation due to remanent biomes. The IFDM index is used for evaluating our society.

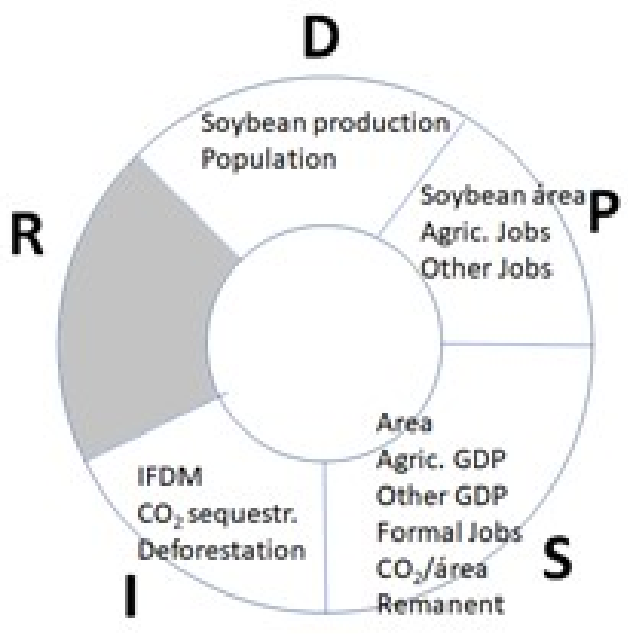

Figure 1. Indicators selected and its structuration their structural framework according to the DPSIR Framework. Source: Authors.

Here, the framework was adopted to link the social and economic aspects included offering a broader vision of the three aspects (social, economic, and environment). The DPSIR does not have a core role in the discussion. However, it contributes as a complementary point of view to understand and support the meaning of the latent variables extracted by the factor analysis method. It allows the proposal of a structure of the relationships among the indicators. The framework is used here to address a linkage perspective and includes social and economic aspects and environmental ones. Indicators related to Response are not considered. However, later, the discussion section will address possible measures to lead with impacts.

\subsection{Mato Grosso State, Municipalities, and the Data Analysis}

At first, in 2018, soybean production in some Mato Grosso municipalities was surveyed. A database of official agencies was used to carry out this study [37]. Within a total of 141 municipalities, data were collected from the 30 largest cities in annual soybean production, which together account for $75 \%$ of total state production, according to official data [37]. Based on this ranking, other indicators were raised better to characterize the cities regarding socio-economic and environmental aspects, as described in Table 2. Mato Grosso is located in the center region of the country and divided into seven macro-regions [46]. The state has three biomes (Figure 2). Amongst these, the largest grain and soybean producing municipalities are distributed. 


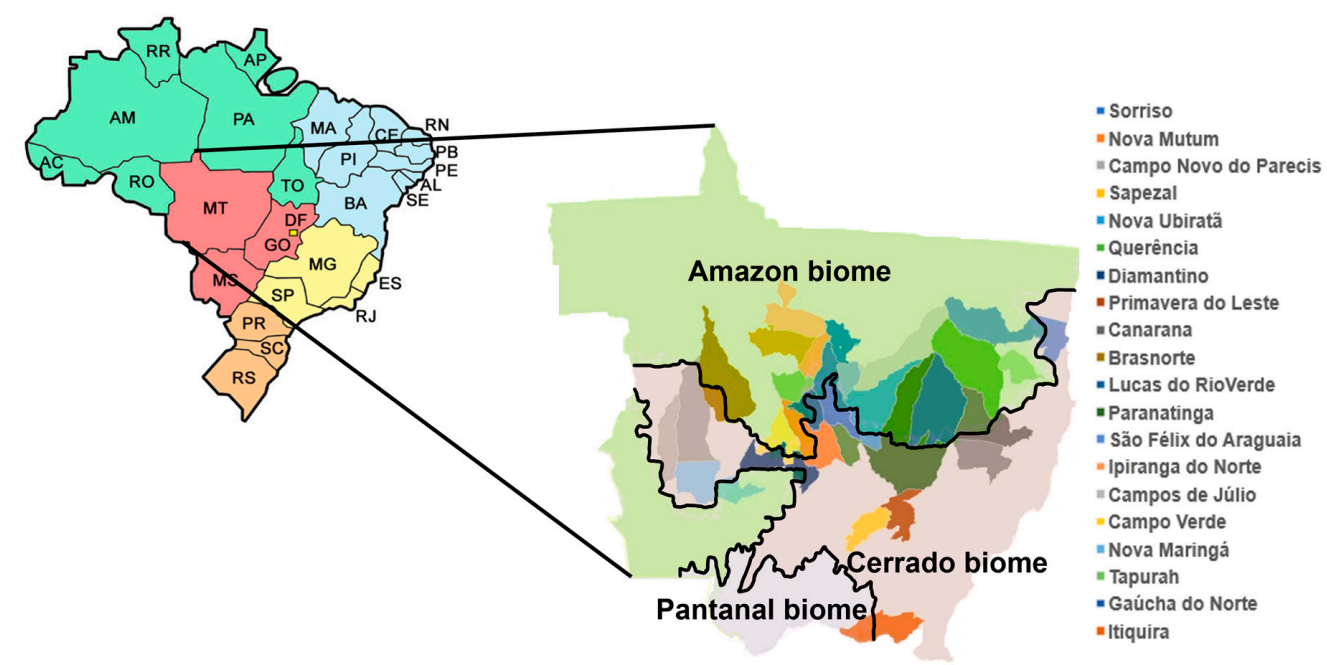

Figure 2. The map of Brazil and the Macro regions, and biome of Mato Grosso State: [37,46].

The Mid-North macro-region is the largest soybean producer in the state. Estimated production for the 2019-2020 harvest according to [17] in 11 million tons, of the 30 municipalities analyzed, 12 belong to this region, these being Sorriso, Lucas do Rio Verde, Sinop, among others. They represent $34 \%$ of the total production in the state. Table 3 highlights the municipality of Sorriso, which alone represents nearly $8 \%$ of all state production, followed by Nova Mutum and Campo Novo do Parecis.

Table 3. Ranking of Mato Grosso municipalities concerning soybean production.

\begin{tabular}{|c|c|c|c|c|c|}
\hline Seq. & Municipality & Production (t) & Seq. & Municipality & Production $(t)$ \\
\hline $1^{\mathrm{o}}$ & Sorriso & $2,232,000$ & $16^{\circ}$ & Campo Verde & 693,000 \\
\hline $2^{\circ}$ & Nova Mutum & $1,335,600$ & $17^{\circ}$ & Nova Maringá & 610,200 \\
\hline $3^{\circ}$ & Campo Novo do Parecis & $1,322,400$ & $18^{\circ}$ & Tapurah & 597,600 \\
\hline $4^{\mathrm{o}}$ & Sapezal & $1,235,400$ & $19^{\circ}$ & Gaúcha do Norte & 579,120 \\
\hline $5^{\mathrm{o}}$ & Nova Ubiratã & $1,218,000$ & $20^{\circ}$ & Itiquira & 561,600 \\
\hline $6^{\circ}$ & Querência & $1,176,000$ & $21^{\circ}$ & Água Boa & 528,000 \\
\hline $7^{\circ}$ & Diamantino & $1,091,880$ & $22^{\circ}$ & Porto dos Gaúchos & 526,612 \\
\hline $8^{\circ}$ & Primavera Do Leste & 890,400 & $23^{\circ}$ & Sinop & 515,040 \\
\hline $9^{\circ}$ & Canarana & 841,500 & $24^{\mathrm{o}}$ & Santa Rita do Trivelato & 511,600 \\
\hline $10^{\circ}$ & Brasnorte & 786,480 & $25^{\circ}$ & Vera & 460,200 \\
\hline $11^{\circ}$ & Lucas do Rio Verde & 772,800 & $26^{\circ}$ & Tabaporã & 445,200 \\
\hline $12^{\circ}$ & Paranatinga & 748,800 & $27^{\circ}$ & Feliz Natal & 410,400 \\
\hline $13^{\circ}$ & São Félix do Araguaia & 746,428 & $28^{\circ}$ & São José do Rio Claro & 390,000 \\
\hline $14^{\mathrm{o}}$ & Ipiranga do Norte & 739,200 & $29^{\circ}$ & Tangará da Serra & 368,880 \\
\hline $15^{\circ}$ & Campos de Júlio & 717,360 & $30^{\circ}$ & Bom Jesus do Araguaia & 360,137 \\
\hline
\end{tabular}

Source: [37].

\section{Results}

Two tests were applied to evaluate the adequacy of data: the Kaiser-Meyer-Olkin (KMO) test and Bartlett's sphericity test. KMO statistic is a proportion of variance among variables that might be common variance: varies from zero to one, in which zero is inadequate, while close to one is adequate. Bartlett's test compares the observed correlation matrix to the identity matrix (off-diagonal is zero) [35] (Table 4). 
Table 4. KMO and Bartlet tests.

\begin{tabular}{clc}
\hline Kaiser-Meyer-Olkin Adequacy & & $\mathbf{0 . 6 5 5}$ \\
\hline & Aprox. Qui-square & 717,437 \\
\cline { 2 - 3 } Bartlett's sphericity test & $\mathrm{ld}$ & 91 \\
\cline { 2 - 3 } & $\mathrm{p}$ & 0 \\
\hline
\end{tabular}

The result of the KMO test was 0.655 , that is, classified as good, meaning that the sample is adequate for the application of factorial analysis. KMO values above 0.50 and $p<0.05$ for Bartlett's test are considered acceptable [35]. There are three significant factors with eigenvalues higher than 1 (Table 5) for an explained variance of $78.1 \%$. The most significant factor is the first $\mathrm{F} 1$ with a variance of $29.9 \%$, followed by the second component, F2, with $24.9 \%$. Both of them represent a cumulative variance of $54.6 \%$. The third one, F3, provided an explained variance of $23.6 \%$.

Table 5. Eigenvalues, proportion of the total variance covered by each factor and the cumulative explanation of data variance.

\begin{tabular}{llll}
\hline & F1 & F2 & F3 \\
\hline Eigenvalue & 4.18 & 3.44 & 3.31 \\
Total explained variance (\%) & 29.9 & 24.9 & 23.6 \\
Cumulative variance (\%) & 29.9 & 54.6 & 78.1 \\
\hline
\end{tabular}

The eigenvectors for the 14 indicators (Table 6) present the most significant components for each indicator are highlighted in bold. The FA reduced dimensionality since the 14 variables were reduced to three, which corresponds to $78 \%$ of the total information.

Table 6. Factorial charges and Communality.

\begin{tabular}{cccccc}
\hline Variable & F1 & F2 & F3 & Initial Communality & Extraction Communality \\
\hline Soybean production & 0.200 & $\mathbf{0 . 9 3 2}$ & 0.135 & 1.00 & 0.902 \\
Soybean area & 0.166 & $\mathbf{0 . 9 4 5}$ & 0.159 & 1.00 & 0.906 \\
Total area & -0.161 & 0.190 & $\mathbf{0 . 6 5 3}$ & 1.00 & 0.621 \\
Deforestation & 0.001 & -0.027 & $\mathbf{0 . 8 8 0}$ & 1.00 & 0.77 \\
Remanent forest & $-0,254$ & -0.022 & $\mathbf{0 . 9 2 7}$ & 1.00 & 0.931 \\
$\mathrm{CO}_{2}$ emission & 0.058 & 0.325 & 0.276 & 1.00 & 0.409 \\
$\mathrm{CO}_{2}$ sequester & -0.179 & -0.053 & $\mathbf{0 . 9 3 2}$ & 1.00 & 0.849 \\
IFDM & 0.347 & 0.226 & -0.265 & 1.00 & 0.425 \\
Jobs other sectors & $\mathbf{0 . 9 8 9}$ & 0.059 & -0.106 & 1.00 & 0.989 \\
Agricultural jobs & 0.213 & $\mathbf{0 . 7 5 4}$ & -0.301 & 1.00 & 0.826 \\
Population & $\mathbf{0 . 9 8 3}$ & 0.065 & -0.079 & 1.00 & 0.964 \\
Formal jobs & $\mathbf{0 . 9 7 6}$ & 0.175 & -0.107 & 1.00 & 0.991 \\
Agric GDP. & 0.157 & $\mathbf{0 . 9 0 1}$ & -0.235 & 1.00 & 0.928 \\
Other sectors GDP & $\mathbf{0 . 9 4 8}$ & 0.258 & -0.111 & 1.00 & 0.979 \\
\hline
\end{tabular}

The municipalities are plotted according to the combined values of their indicators (Figure 3a), proving their similarity. Since it is isolated at the upper right extreme, municipality \#1 (representing Sorriso) has some characteristics different from the others and the two at the lowest second quadrant \#29 and \#23 (Sinop and Tangará da Serra). A cluster is visualized in the third quadrant, whereas the other three quadrants display scattered points and fewer municipalities. 

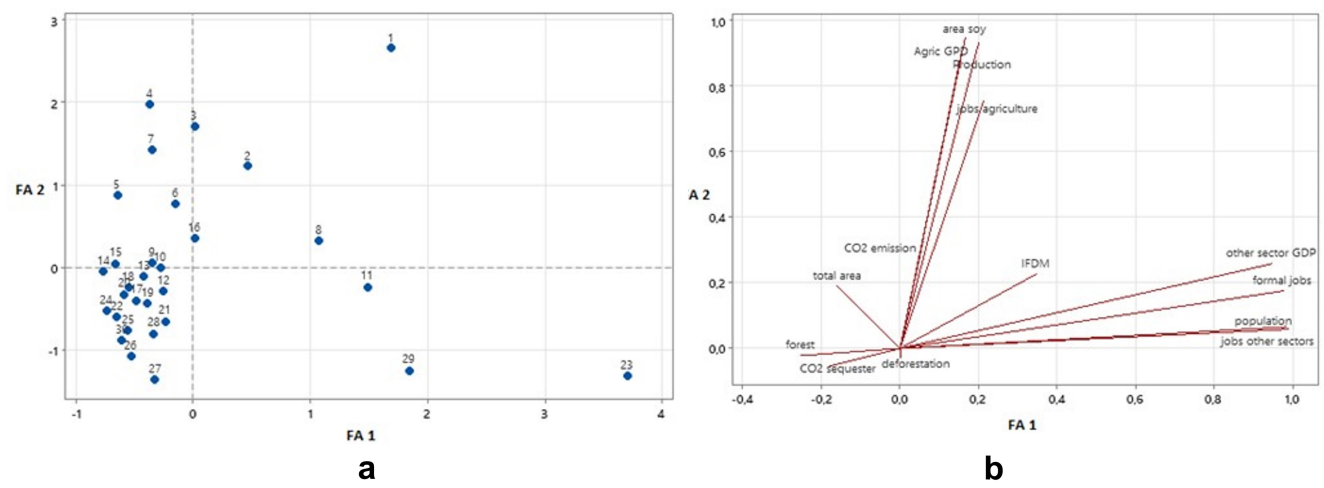

Figure 3. The factor analysis score plot (65.7\% of cumulative variance) (a), and the factor analysis loading plot (b).

Figure $3 \mathrm{~b}$ shows the correlation of the indicators. In this way, the closer the vectors, the more the indicators are correlated. A $90^{\circ}$ angle represents a lack of correlation, whereas a $180^{\circ}$ angle means opposite correlation. The loadings plot shows the relationship between the factors and the original variables, at least for the first two factors F1 and F2.

Population and jobs generated by other sectors of the economy show a high correlation being practically overlapped. GDP from economic sectors other than agricultural and formal jobs correlates well with them and the former two. The strong association among the indicators suggests that formal jobs are generated by the other sectors of the economy instead of the agriculture sector. Another group of indicators has a strong association as the overlapped vectors related to soybean area and production. Although differences in productivity occur among the different regions of the state, they are not important enough to be evidenced in the graph. The biplot in Figure 4 depicts the overlapping loadings and the score plots for the plane formed by F1 and F2.

The closed group located at the third clockwise quadrant has some characteristics in common. These municipalities are associated with high values of remanent forest and $\mathrm{CO}_{2}$ sequestration. They are not associated with high values of jobs from other sectors, population, formal jobs, and GDP generated by the other sectors. Neither is associated with a high GDP of the agriculture sector, soybean, soybean production, and jobs generated in the agriculture sector. The cluster closest points corresponding to municipalities \# 9, 10, $12,13,14,15,17,18,19$, and 20 are primarily situated in the Amazonian region (Canarana, Brasnorte, Paranatinga, São Felix de Araguaia, Ipiranga do Norte, Tapurah, Nova Maringá, Gaúcha do Norte). However, the increasing deforestation over the years presents more rigid legal constraints concerning the percentage of the remanent biome.

Municipalities \#8 and 11, Primavera del Este e Lucas do Rio Verde, are characterized by higher jobs from other sectors, formal jobs, and GDP generated by the other sectors. The ratio between GDP generated by other sectors and agriculture GDP is 3.6 and 5.4 for Primavera del Este and Lucas do Rio Verde. Moreover, the ratios between jobs generated from other sectors and those generated by the agriculture sector are almost 5 and 9 for Primavera del Este and Lucas do Rio Verde. Even among the higher soybean producers, the main economic activities are not directly related to agriculture.

Another cluster is displayed in the fourth quadrant clockwise, related to points \#2, 3, 4, 6, 7, and 16 (Nova Mutum, Campo Novo do Parecis, Sapezal, Querência, Diamantino, and Campo Verde). According to what was interpreted through the loading plots, these municipalities are associated with a relevant GDP of the agriculture sector, soybean, soybean production area, and jobs generated in the agriculture sector. It is important to notice that five of the six that formed the cluster belong to the first seven places according to soybean production. Figure 5 displays the indicators evaluated structured according to the combination of the DPSIR framework and the Factors extracted from the factor analysis. 


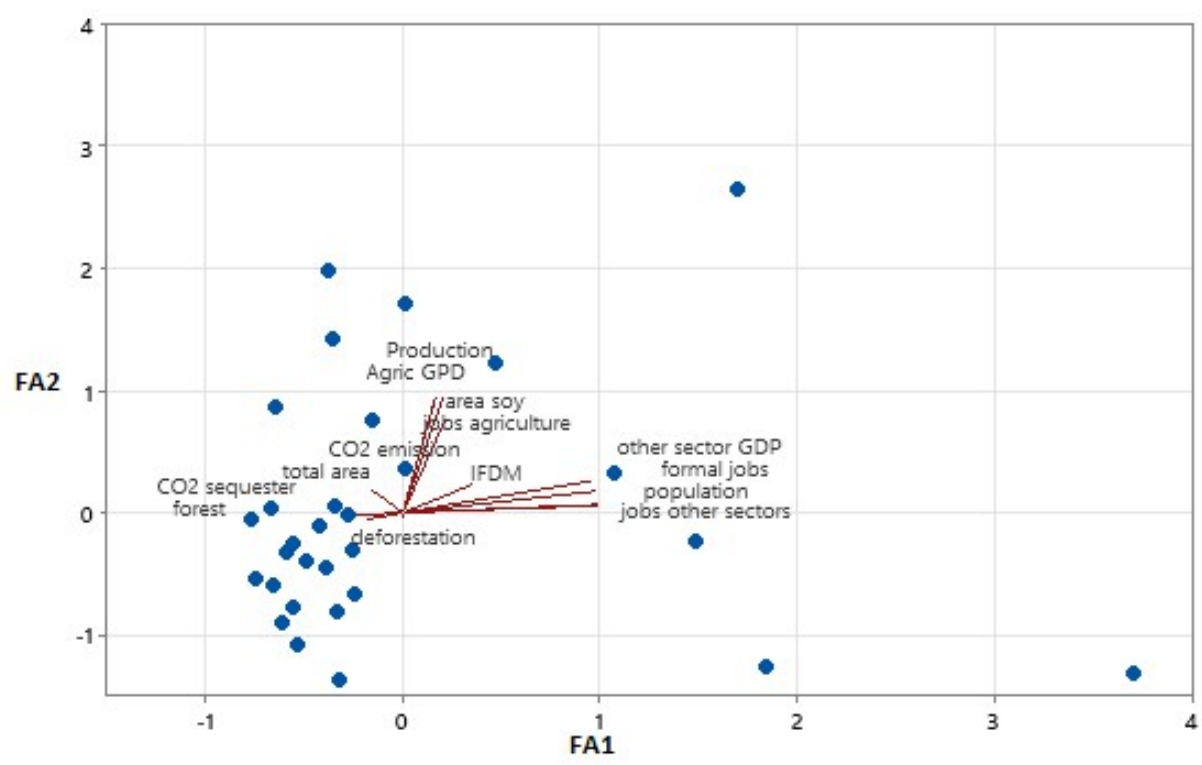

Figure 4. The factor analysis biplot, obtained by the overlapping of Figure $3 a, b$.

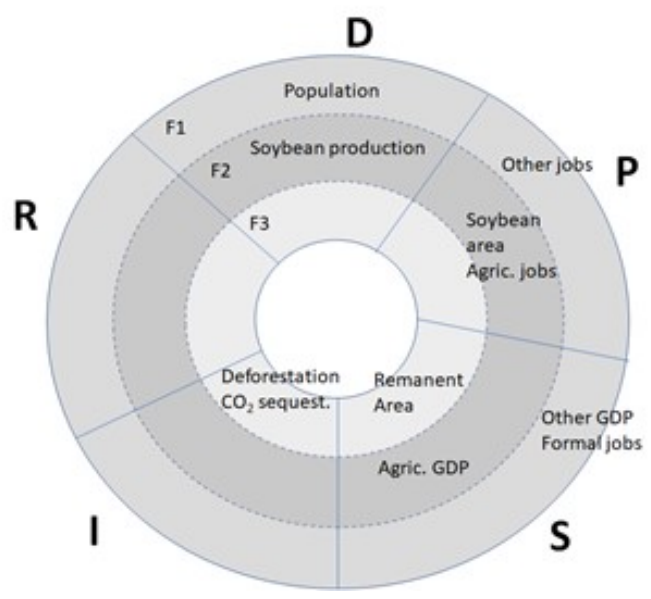

Figure 5. A diagram displays the indicators evaluated structured according to the combination of the DPSIR framework and the Factors extracted from the factor analysis.

\section{Discussion}

The current study analyzed the degree of interaction and positive associations between the economic potential promoted by soybean production and the economic and social development and environmental impacts development within the Driver-PressureState-Impact-Response (DPSRI) framework. We also examined how the largest soybean production regions of the Mato Grosso State behave towards the social, economic, and environmental aspects.

The studied municipalities according to the factors that emerged after the analysis of indicators in factor analysis and interpreted by the DPSRI confirmed a positive interaction between soybean production and the economic, social, and environmental segments. The connection between the soybean production and population is evident, being F1 and F2, and the impact on the indicators such as job creation in non-agricultural sectors and the GPD of different sectors $[10,18,20]$. The soybean production indicator directly impacts the increase in planted areas and agricultural jobs in municipalities. Places with low population density show more agricultural employment with less qualification and agricultural GPD with greater representation [1,19]. The F3, representing the DPSIR framework, was characterized by the remaining area. It evidenced its change of state as the agricultural sector advanced 
in new frontiers. It can reduce these environmental reserves that directly impact emissions and the balance of carbon sequestration $[10,26]$.

In Figure 4, the primary trend expressed on the F1 axis is high values of jobs from other sectors, population, formal jobs, and GDP generated by the other sectors due to the high loading of these indicators. The F2 axis displays high positive loadings of the agriculture sector's GDP, soybean, soybean production area, and Jobs generated in the agriculture sector. Intermediate loading of the indicator $\mathrm{CO}_{2}$ emission is also observed.

As expected, the area of remanent biomes is high correlated with $\mathrm{CO}_{2}$ sequestration (Figure 4). However, it is essential to notice that the amount of sequestration depends on the nature of vegetation [10] since the diverse biomes have different abilities to capture carbon to transform it into biomass. The total area is highly associated with logging. The $\mathrm{CO}_{2}$ emission indicator is almost uncorrelated with remanent biomes and $\mathrm{CO}_{2}$ sequestration.

Results suggest that even the group formed by the biggest producers of soybeans is not homogeneous in terms of social/economic and environmental development (Figure 5). It was demonstrated that three factors that emerged from the FA could explain the group pattern represented by the selected indicators. However, a heterogeneous distribution of how the municipalities develop has different trends to attain high soybean production through environment/society inter-connections. According to a case study in Jiangsu (China), agricultural development's productive/economic factors became more efficient and brought developments [1]. It is important to note that the indicator related to socioeconomic development, the Firjan Index, the IFDM is not strongly correlated with any of the remaining indicators. A plausible interpretation is that positive socio-economic development is associated with multiple factors and does not directly affect agricultural activities and wealth generation.

Municipalities \#8 and 11, Primavera del Este e Lucas do Rio Verde, are characterized by the strong influence of F1. Observation of Figure 5 allows the designing of a trend reflecting their development. Although they are among the higher soybean producers, the main economic activities are other than agriculture activities. Maybe agriculture activities represent de-triggering for the other economic sector. As stated by [18], agribusiness expands the relationship between the primary production segment and the upstream and downstream activities, with a solid connection to technological change, mainly in the job market [1]. This scenario increases citizens' quality of life due to the region's job opportunities generated by industrial units [47].

The cluster displayed in the fourth quadrant clockwise (points \#2, 3, 4, 6, 7, and 16 corresponding to Nova Mutum, Campo Novo do Parecis, Sapezal, Querência, Diamantino, and Campo Verde) is associated with F2 (Figure 3a). The soybean crop area is large, and the generation of jobs is devoted to agricultural activities and consequent generation of GDP. Agricultural jobs require lesser formation and skills than jobs along the upstream chain or at other sectors. The trend represented by the indicators associated with F2 shows that these municipalities are more related to agricultural activities (Figure 5). Any improvement of the development associated with the pattern evidenced at the DPSIR framework will involve more land use for agriculture, increasing productivity, or increasing the number of jobs. The first and the second correlate to high environmental impacts, and the third is improbable to occur. Responses able to solve these problems should be proposed in order to improve development, as explained by $[10,18,20]$. The authors argue that jobs in these municipalities tend to increase within the same agricultural chain $[10,18,20]$.

The closed group (\# 9, 10,12,13,14,15,17,18, 19, and 20) located at the third clockwise quadrant (Figure 3a) has characteristics associated with factor F3 (Figure 5). This group is characterized by relatively big geographical areas, which can offer an advantage to manage land use properly. However, deforestation areas are also high. Since these areas are located in the Amazon region where legal regulation is strict, an equilibrium is demanded to manage high production, extensive geographical areas and, legal constraints (such as the actions to reduce the soybean crops in the legal Amazon area) [25]. 
The impacts linked with the State have positive and negative aspects. Nevertheless, according to Figure 5, the left area of native vegetation is considered a positive expression of the state category. Since the Amazonian Forest has a high $\mathrm{CO}_{2}$ sequestration capacity, the same remanent area will have more weight than another remanent native vegetation. Whether society 'Responds' to impacts depends on how these impacts are perceived and evaluated. In [26], they explained that it is necessary to combine modern agriculture with high diversity and functional ecosystems to improve socio-economic conditions to have a sustainable agricultural system [26]. For those municipalities whose developed trend is explained by F3, controlling and maintaining expansion constraints are mandatory to balance emissions from soybean crops and the balance of sequestration through preserving remaining forests by biomes [10,22].

One limitation of the present study is that the use of indicators as "predictors" for assessing the behavior of the municipalities has some limitations when the municipalities are considered a homogeneous block. We admit that adding more social indicators could improve our findings; however, there are limitations for obtaining a credible and complete database. No indicators showing the kind/agricultural properties were chosen to carry out the analysis, and its inclusion will elaborate more adequate responses.

\section{Conclusions}

Results indicate that there are behavior patterns and taking them into account will help properly use the predictors. Municipalities are expected to be more reactive to some changes than to others to attain a good level of development. There is not a unified way to visualize the more reliable trajectory of the greatest producers.

Combining the DPSIR framework and the Factors extracted from the factor analysis allows visualizing the factors with a less static point of view. The factors can be seen as multilayered. Theoretical approaches indeed sustained DPSIR and FA are different, but we think one could complement this research.

Author Contributions: Conceptualization and development, M.N.V.T., R.C.T., and S.H.B.; methodology, M.N.V.T., R.C.T., H.R.O.S., and S.H.B.; software, M.N.V.T. and S.H.B.; validation, M.N.V.T., R.C.T., and S.H.B.; formal analysis, M.N.V.T., R.C.T. and S.H.B.; research, M.N.V.T., and R.C.T.; resources, M.N.V.T. and curation of M.N.V.T., R.C.T., S.H.B., and H.R.O.S. data; writing-preparing the original draft, M.N.V.T.; writing — proofreading and editing, M.N.V.T., R.C.T., S.H.B., and I.d.A.N.; visualization, M.N.V.T., R.C.T., S.H.B., and I.d.A.N.; supervision, S.H.B.; project administration, M.N.V.T.; acquisition funding, M.N.V.T. All authors read and agreed with the published version of the manuscript.

Funding: Marley Nunes Vituri Toloi wants to thank the Prosup program (CAPES) for the Ph.D. degree scholarship number 8170054 .

Institutional Review Board Statement: Not applicable.

Informed Consent Statement: Not applicable.

Data Availability Statement: The data presented in this study are available on-demand from the first author at (marley.toloi@roo.ifmt.edu.br).

Acknowledgments: To the Coordination for the Improvement of Higher Education PersonnelCAPES, by the finance grant Code 001; to the Federal Institute of Education, Science and Technology of Mato Grosso (IFMT) to support research, and the granting of the training license.

Conflicts of Interest: The authors declare no conflict of interest.

\section{References}

1. Castro, N.R.; de Barros, G.S.C.; Almeida, A.N.; Gilio, L.; de Morais, A.C.P. The Brazilian Agribusiness Labor Market: Measurement, Characterization and Analysis of Income Differentials. Rev. Econ. Sociol. Rural 2020, 58, e192298. [CrossRef]

2. De Nääs, I.A. Introdução ao Agronegócio. In Engenharia de Produção Aplicada ao Agronegócio; dos Reis, J.G.M., de Costa Neto, P.L.O., Eds.; Bluncher: São Paulo, Brazil, 2018; ISBN 978-85-212-1263-8. 
3. Neves, M.F.; Zylbersztajn, D.; Neves, E.M.; Rodrigues, R. Agronegócio do Brasil; Saraiva: São Paulo, Brazil, 2006; ISBN 978-85-02-05378-6.

4. De Embrapa, E.B.P.A. Visão 2030: O Futuro da Agricultura Brasileira; Embrapa: Brasília, Brazil, 2018; ISBN 978-85-7035-799-1.

5. Da Mapa, M.A. Pecuária e Abastecimento. Valor da Produção Agropecuária é de R\$5656 Bilhões. Available online: http: //www.agricultura.gov.br/noticias/valor-da-producao-agropecuaria-e-de-r-565-6-bilhoes (accessed on 23 June 2021).

6. Abraham, E.R.; Mendes dos Reis, J.G.; Vendrametto, O.; de Oliveira Costa Neto, P.L.; Carlo Toloi, R.; de Souza, A.E.; de Oliveira Morais, M. Time Series Prediction with Artificial Neural Networks: An Analysis Using Brazilian Soybean Production. Agriculture 2020, 10, 475. [CrossRef]

7. Mourão, R.; da Silva Lino, E.N. Expansão Agrícola no Cerrado: O desenvolvimento do Agronegócio no Estado de Goiás entre 2000 a 2019. Caminhos Geogr. 2021, 22, 1-17. [CrossRef]

8. Dall'Agnol, A. A Soja no Contexto do Desenvolvimento da Soja No Brasil: Histórico e Contribuições, 1st ed.; Embrapa: Brasília, Brazil, 2016; ISBN 978-85-7035-558-4.

9. Hirakuri, M.H.; Lazzarotto, J.J. O Agronegócio da Soja nos Contextos Mundial e Brasileiro. 2014. Available online: https: / / ainfo.cnptia.embrapa.br/digital/bitstream/item/104753/1/O-agronegocio-da-soja-nos-contextos-mundial-e-brasileiro.pdf (accessed on 25 September 2021).

10. Lima, M.; Skutsch, M.; de Costa, G.M. Deforestation and the Social Impacts of Soy for Biodiesel: Perspectives of Farmers in the South Brazilian Amazon. Ecol. Soc. 2011, 16, art4. [CrossRef]

11. Mendes dos Reis, J.G.; Sanches Amorim, P.; Sarsfield Pereira Cabral, J.A.; Toloi, R.C. The Impact of Logistics Performance on Argentina, Brazil, and the US Soybean Exports from 2012 to 2018: A Gravity Model Approach. Agriculture 2020, 10, 338. [CrossRef]

12. De Conab, C.N.A. Conab-Série Histórica das Safras; Conab: Brasília, Brazil, 2021.

13. FAS/USDA World Agricultural Production; USDA-United States Department of Agriculture: Washington, DC, USA, $2021 ;$ p. 41.

14. Da Rocha, F.V.; João, A.M.; Costa, E.L.; Caixeta Filho, J.V. Política de Precificação de GEE: Impactos Econômicos e Ambientais na Agrologística de Grãos no Mato Grosso. Rev. Políticas Públicas 2020, 24, 137-155. [CrossRef]

15. De Miranda, E.E.; de Carvalho, C.A.; Oshiro, O.T. Atribuição, Ocupação e Uso das Terras No Estado Do Mato Grosso; Atribuição, Uso e Ocupação de Mato Grosso; EMBRAPA: Campinas, Brazil, 2017.

16. Comexstat Exportação e Importação Municípios. Available online: http:/ / comexstat.mdic.gov.br/pt/municipio (accessed on 25 September 2021).

17. De Imea, I.M.G.; Boletim de Soja, E.A. Boletim Semanal; IMEA: Cuiabá, Brazil, 2021; p. 14.

18. Castro, L.S.; Miranda, M.H.; Lima, J.E. Indicadores Sociais de Desenvolvimento e a Produção de Soja: Uma Análise Multivariada nos 150 Maiores Municípios Produtores Brasileiros. Rev. Bras. Gest. Desenvolv. Reg. 2015, 11, 69-87.

19. Russo Lopes, G.; Bastos Lima, M.G.; dos Reis, T.N.P. Maldevelopment Revisited: Inclusiveness and Social Impacts of Soy Expansion over Brazil's Cerrado in Matopiba. World Dev. 2021, 139, 17. [CrossRef]

20. Richards, P.; Pellegrina, H.; VanWey, L.; Spera, S. Soybean Development: The Impact of a Decade of Agricultural Change on Urban and Economic Growth in Mato Grosso, Brazil. PLoS ONE 2015, 10, e0122510. [CrossRef]

21. De Almeida, P.G.; Reinaldo, L.R.L.R.; de Sousa Alves, L.; da Silva Sousa, J.; Maracajá, P.B.; Wanderley, J.A.C.; dos Santos, D.P. Impactos Ambientais Causados pela Agricultura e a Pecuária nas propriedades São João e Areia Branca, Pombal-PB. Rev. Bras. Gest. Ambient. 2010, 4, 34-63.

22. Raucci, G.S.; Moreira, C.S.; Alves, P.A.; Mello, F.F.; de Almeida Frazão, L.; Cerri, C.E.P.; Cerri, C.C. Greenhouse Gas Assessment of Brazilian Soybean Production: A Case Study of Mato Grosso State. J. Clean. Prod. 2015, 96, 418-425. [CrossRef]

23. Dall'Agnol, A.; Lazarotto, J.J.; Hirakuri, M.H. Desenvolvimento, Mercado, Rentabilidade da Soja Brasileira. 2010. Available online: https: / / www.embrapa.br/busca-de-publicacoes/- / publicacao/854125/desenvolvimento-mercado-rentabilidade-dasoja-brasileira (accessed on 25 September 2021).

24. De Freitas, P.L.; Landers, J.N. The Transformation of Agriculture in Brazil Through Development and Adoption of Zero Tillage Conservation Agriculture. Int. Soil Water Conserv. Res. 2014, 2, 35-46. [CrossRef]

25. Prudêncio da Silva, V.; van der Werf, H.M.G.; Spies, A.; Soares, S.R. Variability in Environmental Impacts of Brazilian Soybean According to Crop Production and Transport Scenarios. J. Environ. Manag. 2010, 91, 1831-1839. [CrossRef]

26. Martinelli, L.A.; Naylor, R.; Vitousek, P.M.; Moutinho, P. Agriculture in Brazil: Impacts, Costs, and Opportunities for a Sustainable Future. Curr. Opin. Environ. Sustain. 2010, 2, 431-438. [CrossRef]

27. Martine, G.; Alves, J.E.D. Economia, Sociedade e Meio Ambiente no Século 21: Tripé ou Trilema da Sustentabilidade? Rev. Bras. Estud. Popul. 2015, 32, 433-460. [CrossRef]

28. Smeets, E.; Weterings, R. Environmental Indicators: Typology and Overview; TNO Centre for Strategy, Technology and Policy; European Environment Agency: Copenhagen, Denmark, 1999; p. 19.

29. Hannouf, M.B.; Assefa, G.; Hannouf, M.B.; Gates, I. Cause-Effect Chains in S-LCA Based on DPSIR Framework Using Markov Healthcare Model: An Application to "Working Hours" in Canada. Int. J. Life Cycle Assess. 2021, 26, 936-949. [CrossRef]

30. Zhou, S.; Mueller, F.; Burkhard, B.; Cao, X.; Hou, Y. Assessing Agricultural Sustainable Development Based on the DPSIR Approach: Case Study in Jiangsu. China J. Integr. Agric. 2013, 12, 1292-1299. [CrossRef]

31. Gilandeh, A.G.; Behjou, F.K.; Yarmohammadi, K. Evaluation of Ardabil City Carrying Capacity Using DPSIR Method and ELECTRE Model. Glob. J. Agric. Innov. Res. Dev. 2018, 5, 15-23. [CrossRef] 
32. De Araújo, M.D.; Ribeiro, M.M.R.; Braga, C.F.C. Integrando a Modelagem da Alocação de Água ao Sistema de Indicadores FPEIR: Aplicação ao Semiárido do Brasil. Eng. Sanit. Ambient. 2019, 24, 1167-1181. [CrossRef]

33. Porto, D.T.; Basso, L.A.; Strohaecker, T.M. Diagnóstico Ambiental da Bacia Hidrográfica do Rio Mampituba, Região Sul do Brasil, Utilizando a Matriz FPEIR. Geosul 2019, 34, 28-50. [CrossRef]

34. De Santos, R.O.; Gorgulho, B.M.; de Castro, M.A.; Fisberg, R.M.; Marchioni, D.M.; Baltar, V.T. Principal Component Analysis and Factor Analysis: Differences and Similarities in Nutritional Epidemiology Application. Rev. Bras. Epidemiol. 2019, 22, e190041. [CrossRef]

35. Field, A.; Miles, J.; Field, Z. Discovering Statistics Using R, 1st ed.; Sage: London, UK, 2012; p. 992, ISBN 978-1-4462-0046-9.

36. Toloi, R.C.; da Gunes, A.C.R.S.L.; Toloi, M.N.V.; dos Reis, J.G.M.; Bonilla, S.H.; Freitas, M.J. Main Variables That Are Influenced by the Anthropic Activity Resulting from the Soybean Production in the Municipalities of Mato Grosso. Indep. J. Manag. Prod. 2018, 9, 607-622. [CrossRef]

37. Instituto Brasileiro de Geografia e Estatística. Pesquisa Agrícola Municipal; IBGE: Brasília, Brazil, 2021.

38. De Inpe, I.N.P.E. Projeto Prodes. Available online: http:/ / www.dpi.inpe.br/prodesdigital/prodesmunicipal.php (accessed on 5 September 2021).

39. Toloi, M.N.V.; Toloi, R.C.; Bueno, R.E.; Bonilla, S.H. Análise das Emissões de $\mathrm{CO}_{2}$ dos Insumos da Cultura da Soja nos Âmbitos Upstream e Direto em Diferentes Macrorregiões do Estado de Mato Grosso-Brasil. Rev. Cuba. Ing. 2021, 12 , e293.

40. FIRJAN IFDM-Índice FIRJAN de Desenvolvimento Municipal; Federação das Indústrias do Estado do Rio de Janeiro-FIRJAN: Rio de Janeiro, Brazil, 2018.

41. Ministério da Economia Relação Anual de Informações Sociais. Available online: http://www.rais.gov.br/sitio/index.jsf (accessed on 25 September 2021).

42. Instituto Brasileiro de Geografia e Estatística. Mato Grosso I Cidades e Estados I. Available online: https:/ /www.ibge.gov.br/ cidades-e-estados/mt.html (accessed on 25 September 2021).

43. Tonello, V.M.M. Principais Aspectos do Ciclo Biogeoquímico do Elemento Carbono e seu Contexto na Atualidade. Master's Thesis, Universidade de São Paulo, Piracicaba, Brazil, 2007.

44. Milne, E.; Cerri, C.E.P.; Carvalho, J.L.N. Agricultural expansion in the Brazilian state of Mato Grosso; implications for C stocks and greenhouse gas emissions. In Tropical Rainforests and Agroforests under Global Change; Tscharntke, T., Leuschner, C., Veldkamp, E., Faust, H., Guhardja, E., Bidin, A., Eds.; Environmental Science and Engineering; Springer: Berlin/Heidelberg, Germany, 2010; pp. 447-460. [CrossRef]

45. Griffiths, P.; Jakimow, B.; Hostert, P. Reconstructing Long Term Annual Deforestation Dynamics in Pará and Mato Grosso Using the Landsat Archive. Remote Sens. Environ. 2018, 216, 497-513. [CrossRef]

46. Instituto Mato-Grossense de Economia Agropecuári. Mapa de Microrregiões do IMEA; IMEA: Cuiabá, Brazil, 2017.

47. De Araújo, F.A.O.M.; Boaventura, D.M.R. Os Municípios do Agronegócio no Estado do Mato Grosso: Efeitos e defeitos da atividade da moderna agricultura. Rev. Geogr. Acad. 2020, 14, 100-122. 